\title{
Analisa Kandungan Senyawa Metabolit Sekunder Ekstrak Daun Ketepeng Cina (Cassia alata L.) dari Bireum Bayeun, Aceh Timur
}

\author{
Nurul Asmah ${ }^{1}$, Halimatussakdiah ${ }^{1 *}$, dan Ulil Amna ${ }^{1}$ \\ ${ }^{1}$ Program Studi Kimia Fakultas Teknik Universitas Samudra \\ Jl. Meurandeh, Langsa Aceh 24416, Indonesia \\ *Corresponding author: halimatussakdiah@unsam.ac.id
}

\begin{abstract}
ABSTRAK
Ketepeng Cina (Cassia alata L.) banyak ditemukan di dalam hutan hujan tropika yang memiliki sekitar 1.260 spesies. Tumbuhan ini merupakan salah satu objek utama yang penting bagi para ilmuan untuk pengobatan infeksi dan kanker. Selain itu, daun ketepeng cina juga mempunyai peranan yang sangat besar dalam bidang kesehatan karena menghasilkan zat-zat kimia yang memiliki kegunaan yang potensial dalam pengobatan hepatitis, ganguan kulit, penyakit kuning, dan eksema. Namun, tumbuhan ini sudah sangat jarang digunakan untuk kehidupan sehari-hari sehingga tanaman ini sering sekali dibasmi oleh masyarakat. Penelitian ini bertujuan untuk mengidentifikasi senyawa metabolit sekunder pada daun segar dan daun kering Ketepeng Cina (C. alata L.) yang diambil dari kecamatan Birem Bayeun kabupaten Aceh Timur. Pada daun segar menunjukkan adanya alkaloid, steroid, terpenoid, saponin, flavonoid, fenol dan dan tanin. Sedangkan pada daun kering menunjukkan adanya alkaloid, fenol dan tanin.
\end{abstract}

Kata kunci: Cassia alata, metabolit sekunder, ketepeng Cina, dan Aceh Timur

\section{PENDAHULUAN}

Tumbuhan ketepeng Cina (Cassia alata L. atau juga sering disebut sebagai Senna alata L.) tersebar luas di daerah tropis yang memiliki sekitar 1.260 spesies [1 2, 3]. Di Indonesia tumbuhan ketepeng cina memiliki sebutan yang berbeda-beda yaitu ketepeng kebo (jawa), ketepeng badak (sunda), acon-aconan (Madura), sajamera (Halmahera), kupang-kupang (ternate), tabankun (tidore), daun kupang, daun kurapan dan gelinggang (Sumatra) [4].

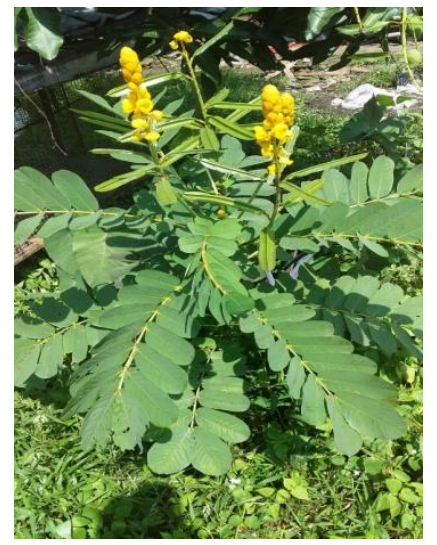

Gambar 1. Tumbuhan Ketepeng Cina (Cassia alata L.)

Tumbuhan ketepeng cina ini dikenal sebagai pohon lilin, tanaman kurap dan semak lilin [5]. Daun ketapang sudah sangat jarang digunakan untuk kehidupan sehari-hari sehingga tanaman ini sering sekali dibasmi oleh masyarakat [6].

Daun ketepeng cina berbentuk jorong (Gambar 1) hampir mirip dengan daun jambu biji yang merupakan daun majemuk menyirip yang berpasang-pasangan sebanyak $5-12$ baris $[7,8]$. Daun ketepeng cina ( $C$. alata L.) mempunyai peranan yang sangat besar dalam bidang kesehatan karena menghasilkan zat-zat kimia yang memiliki kegunaan yang potensial dalam pengobatan hepatitis, ganguan kulit [2]. penyakit kuning, dan eksema [9, 10]. Tanaman ini juga merupakan hal utama yang penting bagi para ilmuan yaitu sebagai pengobatan infeksi dan kanker [11]. Daun ketepeng mengandung zat kimia yang memiliki aktivitas antibakteri dan antijamur yang bersifat toksik terhadap jamur [5, $12,13,14,15,16,17]$. Seorang kimiawan juga menyatakan bahwa ekstrak dari daun ketepeng cina dapat menghambat pertumbuhan mikroba $[8,18]$.

Daun ketapang merupakan salah satu bahan aktif alami yang mengandung alkaloid, saponin, flavonoid, karbohidrat, glikosida, tanin, triterpenoid dan turunan antrakuinon $[4,6,8,14$, $19,20,21,22]$. Senyawa saponin mempunyai efek yang menghambat kerja dari enzim khemotripsin, asetilkoline sterase dan preoteinase yang menyebabkan paralis spatik otot yang dapat menyebabkan kematian [22]. 
Ekstrak dari daun ketepeng cina (C. alata L.) dilakukan dengan beberapa pelarut dan dengan berbagai teknik yang dilakukan sehingga menunjukkan adanya aktivitas antimikroba $[1,5]$. Fitokimia dari daun ketepeng cina ini dikenal karna sifat sitotoksiknya terhadap berbagai sel yaitu diantaranya sel kanker [23]. Flavonoid merupakan golongan pada senyawa fenol yang pigmen tumbuhan [14].

Berdasarkan beberapa literatur tersebut, dilakukan analisa kandungan senyawa metabolit sekunder ekstrak daun ketepeng Cina (C. alata L.) yang diambil dari kecamatan Bireum Bayeun, kabupaten Aceh Timur.

\section{BAHAN DAN METODE}

\section{Bahan}

Bahan-bahan yang digunakan dalam penelitian ini adalah metanol, etil asetat, $n$ heksana, kloroform, asam sulfat, pereaksi Meyer, pereaksi Dragendorff, pereaksi Wagner, pereaksi Liberman-Bourchard, etanol $80 \%, \mathrm{HCl}$ $0,5 \mathrm{M}$, dan $\mathrm{FeCl}_{3}$.

\section{Metode}

\section{a. Penangan sampel}

Daun Ketepeng Cina (Cassia alata L.) sebanyak $10 \mathrm{gr}$ diambil dari desa merbou II kecamatan Birem Bayeun kabupaten Aceh Timur provinsi Aceh. Daun diambil pada bulan April 2019 kemudian daun dikeringanginkan. Daun yang sudah kering dihaluskan hingga diperoleh serbuk kering yang kemudian dilakukan uji kandungan metabolit sekunder.

\section{b. Uji alkaloid}

Sekitar 1 gram sampel dihancurkan lalu ditambahkan $1 \mathrm{~mL}$ amonia. Kemudian ditambahkan $10 \mathrm{~mL}$ kloroform, lalu digerus dan disaring. Ditambahkan $10 \mathrm{~mL}$ asam sulfat $2 \mathrm{~N}$, ke dalam filtrat dan dikocok kuat-kuat, dibiarkan selama satu menit sampai larutan asam sulfat dan kloroform memisah. Lapisan asam sulfat diambil dan dibagi menjadi tiga tabung reaksi dan setiap tabung reaksi diuji dengan pereaksi Meyer, Dragendorff, dan Wagner untuk menentukan keberadaan alkaloid. Penambahan reagen Meyer membentuk endapan putih, reagen Dragendorff menyebabkan endapan kemerahan, dan reagen Wagner menghasilkan endapan kuning. Perubahan tersebut menunjukkan adanya alkaloid [24].

\section{c. Uji Terpenoid, Steroid, dan Saponin}

Sebanyak 1 gram sampel ditumbuk halus, kemudian diekstraksi dengan metanol panas. Filtrat yang diperoleh dipekatkan dengan rotary evaporator untuk menghasilkan ekstrak metanol. Ekstrak metanol dipartisi dengan $n$-heksana. Ekstrak larut dalam $n$-heksana diuji dengan reagen Liberman-Bourchard. Terbentuknya warna biru atau hijau menunjukkan adanya steroid dan warna merah untuk terpenoid. Residu yang tidak larut dalam $n$-heksana ditambahkan air dan terguncang dengan kuat. Apabila terbentuk busa stabil selama 30 menit, hal tersebut menunjukkan adanya saponin, jika positif untuk saponin, larutan dihidrolisis dengan $\mathrm{HCl}$ dan diuji dengan pereaksi LibermanBourchard. Warna hijau atau biru menunjukkan adanya saponin steroid dan warna ungu atau merah menunjukkan adanya saponin terpenoid [24].

\section{d. Uji Flavonoid}

Sampel sebanyak 1 gram diekstraksi dengan metanol dan dipekatkan. Ekstrak metanol pekat dipartisi dengan $n$-heksana. Residu diekstraksi dengan $10 \mathrm{~mL}$ etanol $80 \%$, kemudian ditambahkan $0,5 \mathrm{mg}$ serbuk magnesium dan $\mathrm{HCl}$ $0,5 \mathrm{M}$. Warna merah muda atau ungu menunjukkan adanya flavonoid [24].

\section{e. Uji Fenol}

Ekstrak metanol sampel diuji dengan $\mathrm{FeCl}_{3}$. Tambahkan 3 - 4 tetes larutan $\mathrm{FeCl}_{3}$ ke dalam ekstrak, pembentukan warna hitam kebiruan menunjukkan senyawa fenol [24].

\section{f. Uji Tanin}

Sebanyak 1 gram ekstrak metanol sampel direbus dalam $10 \mathrm{ml}$ air dalam tabung reaksi dan kemudian disaring. Tambahkan beberapa tetes $\mathrm{FeCl} 30,1 \%$. Pembentukan warna hijau kecoklatan atau hitam kebiruan menunjukkan tanin [24].

\section{HASIL DAN PEMBAHASAN}

Daun ketepeng Cina (C. alata L.) yang telah dibersihkan kemudian dikeringanginkan pada suhu kamar. Daun yang telah kering dihaluskan dengan menggunakan blender atau digunting 
sampai halus dengan tujuan untuk memperluas permukaan dari daun ketepeng cina. Sampel tersebut kemudian dianalisis kandungan senyawa metabolit sekunder, hasil pengujiannya ditabulasikan pada Tabel 1.

Tabel 1. Hasil analisa kandungan senyawa metabolit sekunder ekstrak daun ketepeng Cina (C. alata L.)

\begin{tabular}{cccc}
\hline No & $\begin{array}{c}\text { Metabolit } \\
\text { Sekunder }\end{array}$ & $\begin{array}{c}\text { Daun } \\
\text { Kering }\end{array}$ & $\begin{array}{c}\text { Daun } \\
\text { Segar }\end{array}$ \\
\hline & Alkaloid : & & + \\
1 & - D & + & + \\
& - M & + & + \\
& - W & + & + \\
2 & Terpenoid & - & + \\
3 & Steroid & - & + \\
4 & Saponin & - & + \\
5 & Flavonoid & - & + \\
6 & Fenol & + & + \\
7 & Tanin & + & + \\
\hline
\end{tabular}

Pada sampel daun kering dan daun segar menunjukkan adanya kandungan alkaloid dengan terbentuknya endapan pada semua reagen.

Pada uji terpenoid, steroid, saponin dan flavonoid pada daun segar menujukkan adanya hasil yang positif. Sedangkan pada daun yang kering tidak menunjukkan adanya senyawa tersebut. Hal ini dapat disebabkan oleh proses pengeringan sampel yang membuat senyawa tersebut tidak terdeteksi pada daun kering. Disisi lain, identifikasi kandungan senyawa fenol dan tanin menunjukkan hasil yang positif pada kedua sampel, baik pada daun kering maupun pada daun segar.

Secara umum, metabolit sekunder yang terkandung dalam tumbuhan ini adalah senyawa polar, yang disebabkan oleh pelarut yang digunakan adalah polar. Meskipun metanol cenderung menarik hampir semua jenis senyawa polaritas, tetapi senyawa dalam tumbuhan tersebut ini, hampir semua senyawa yang terdeteksi adalah senyawa polar [24].

Alkaloid merupakan senyawa siklik yang mengandung atom nitrogen yang penyebarannya terbatas pada organisme hidup. Efek fisiologis yang kuat dan selektifitas senyawa alkaloid menyebabkan senyawa alkaloid tersebut sangat bermanfaat dalam hal pengobatan. Flavonoid merupakan golongan pada senyawa fenol yang pigmen tumbuhan [14]. Steroid merupakan salah satu golongan senyawa yang sangat penting dalam bidang kesehatan. Saponin merupakan glikosida atau detergen alami yang memiliki sifat aktif yang bersifat amfifilik dan mempunyai berat molekul yang terdiri dari aglikon steroid atau triterpen. Tanin merupakan senyawa fenol yang mengandung protein.

\section{KESIMPULAN}

Berdasarkan analisa kandungan senyawa metabolit sekunder ekstrak daun ketepeng Cina (C. alata L.) menunjukkan bahwa pada daun kering menunjukkan adanya senyawa alkaloid, fenol dan tannin. Sedangkan dada daun segar diperoleh adanya senyawa alkaloid, steroid, terpenoid, saponin, flavonoid, fenol dan dan tannin. Senyawa metabolit sekunder yang terkandung dalam daun ketepeng cina adalah senyawa polar, yang disebabkan oleh pelarut yang digunakan adalah polar.

\section{REFERENSI}

[1] Ayobami O. Oyedele, Ezekiel O. Doyinsola D. Fabiyi and Lara O. Orafidiya. 2017. Physicochemical Properties and Antimicrobial Activities Of Soap Formulations Containing Senna alata and Eugenia Uniflora Leaf Preparations. Journal of Medicinal Plants Research. 11 (48) : 778-787.

[2] Chewchinda, S and Sithissarn. 2017. Simultaneous HPTLC Determination of Aloe-emodin in Senna alata Leaves from Thailanand Their Commercial Products. Natural Product Communications. 12 (3) : 399-401.

[3] Sarathadevi, D and Somasundram. 20 Clinical Pathogens. 2015. Stusies On Antibacterial Activities of Senna alata (L.)Against Clinical Pathogens. Journal od Microbiology and Biotechnology Research. $5(3): 1-6$.

[4] Fajri, M., Marfu'ah,N., Artanti,LO. 2018. Aktivitas Antifungi Daun Ketepeng Cina (Cassia Alata L.) Fraksi Etanol, $\mathrm{N}$-Heksan, dan Kloroform Terhadap Jamur Micrisporium canis. Pharmasipha. 2 (1) : 1 8.

[5] Ugbogu, E A., Okezie, E., Elekwa, I., Uhegbu, F., Akubugwo, E., Chinyere, C G., Ewuzie, F and Ugorji, C J., 2016. Toxicological Assessment of the Aques Dried Leaf Extracts of Senna alata L. in Rats. Journal 
of Pharmacy and Pharmacology. 10 (34): 709-717.

[6] Aisyah., putri, K.A., Suriani., Iswandi., Ilyas, A. 2017. Pengaruh Kandungan pada Ekstrak Daun Ketepeng n- Heksan, Etil Asetat, Metanol dan Campuran Terhadap Nilai Efisien Sensitized cell (DSSC). Al-Kimia . $5 \quad$ (2) : 170-180.

[7] Sesa,OE., Sulastry,T., Muharram. 2015. Isolasi Dan Identifikasi Senyawa Metabolit Sekunder Ekstrak Metanol Daun Ketepeng Cina (Cassia Alata Linn). Jurnal Chemical. 15 (1):136-143.

[8] Anwar, Adi.N.D. 2015. Manfaat Daun Ketepeng Cina (Cassia alata L.) sebagai Antifungi pada Tinea Predis. Agromed Unila. 2 (4) : 385-388. Jimvet. 01 (1) : 040-045.

[9] Rahmawati., Muflihunna, A., Kusuma, AT., Hardiyanti. 2015. Analisa Kadar Flavonoid Dan Fenolik Total Fraksi Etil Asetat Daun Ketepeng Cina (Senna alata (L.) Roxb) Dengan Metode Spektrofotometri UvVisible. As-Syifaa. 07 (01) : 10-18.

[10] Nurlansi dan Jahidin . 2017. Uji Aktivitas Antibakteri Ekstrak Metanol dan Fraksi Etilasetat Daun Ketepeng Cina (Cassia alata L.). Indonesia Natural Research Pharmaceutical Journal. 2 (2) : 13-18.

[11] Ramadhian, M.R., Soleha, T.U., Hanriko, R., dan Azkia, H.P. 2017. Pengaruh Ekstrak Metanol Daun Ketapang (Terminalia catappa L.) terhadap Kepadatan Serabut Kolagen pada Penyembuhan Luka Sayat Mencit (Mus musculus). J AgromedUnila. 4 (1): 17-24.

[12] Linda, R., Khotimah, S., dan Elfiani. 2016. Aktivitas Ekstrak Daun Ketepeng Cina (Cassia alata Linn) terhadap Pertumbuhan jamur Cecospora perseonatum. Jurnal Biopropal Industri. 02. (01): 1-7.

[13] Alioes, Y., Krtika,A., Zain, EA., Azzura,V. 2018. Uji Potensi Antijamur Candida Albicans Ekstrak Daun Gelinggang (Cassia Alata L.) Dibandingkan Dengan Sediaan Daun Sirih Yang Beredar Dipasaran Secara In Vitro. Jurnal Kimia Riset. 3 (2) :108-115.

[14] Mahmudah, R., Abdullah, N., Pratiwi, A., Hidayah, M.A., Ismail, R. 2018. Uji Efektifitas Ekstrak Etanol Daun Ketepeng Cina (Cassia alata L.) Terhadap Mikroba Penyebab Sariawan (Stomatitis Aphtosa). Jurnal Mandala Pharmacon Indonesia. 4 (1) : 39-52.

[15] Triana, O., Prasetya, F., Kuncoro, H., dan Rijai,L. 2016. Aktivitas Antijamur Ekstrak Daun Ketepeng Cina (Cassia alata L.). Jurnal Sains dan Kesehatan. 1 (6): 311-315.

[16] Rezali., Tandi, J., dan Anggi, V. 2018. Daya Hambat Ekstrak Terpurifikasi Daun Ketepeng Terhadap Bakteri Escherichia coli dan Staphylococcus aureus. Jurnal Farmasi. XV (2):152-159.

[17] Ladyescha, D., Nugroho, R.A., dan Dharma, B. 2015. Uji Efektivitas Ekstrak Car Daun Ketapang (Terminalia catappa Linn.) Sebagai Antibakteri Terhadap Ikan Cupang (Betta sp) yang Diinfeksi Bakteri Salmonella entertica Serovar Typhi. Sains dan Teknologi FMIPA Unmul. 1 (3): 27-34.

[18] Silviani, dan Utomo, L.B. 2017. Efektivitas Varian Konsentrasi Ekstrak Etanol Daun Ketepeng Cina Terhadap Pertumbuhan Shigella Dysentriae. Biomedika. 10 (1): 1218.

[19] Oktarya, Z., dan Saputra, R. 2015. Pengaruh Jenis Pelarut Terhadap Jumlah Ekstrak Dan Daya Antifungi Daun Ketepeng Cina (Cassia alata L.) Terhadap Jamur Trychophyton Sp. Jurnal Photon. 5 (2) : 1521.

[20] Tambaru, E. 2017. Keragaman Jenis Tumbuhan Obat Indigenous di Sulawesi selatan. Jurnal IImu Alam dan Lingkungan. 8. (15):7-13.

[21] Gani, A. A., Mukarlina, dan Rusmiyanto, P. E. 2017. Profil GC-MS dan Potensi Bioherbisida Ekstrak Metanol Daun Ketapang (Terminalia catappa L.) terhadap Gulma Maman Ungu (Cleome rutidosperma D.C). Jurnal Protobiont. 6 (2): 22-28.

[22] Iman, F., Waluyo, J., dan Asyiah, I. N. 2015. Pengaruh Variasa Konsentrasi Ekstraksi Daun Ketepeng Cina (Cassia alata L.) terhadap Mortalitas Cacing Ascaris suum Dewasa secara In Vitro. Pancaran. 4 (2): 71-82.

[23] Okerenta, B O., Sprigg, K., Bradshaw, T. 2018. Ethyl Acetat of Senna alata (L) Roxb Increases Cytotoxicity in the Human Breast, Prostate and Colorectal Cancer Cells. Journal of Cancer Treatment and Research. 6 (3): 44-53.

[24] Halimatussakdiah., Amna, U., dan Wahyuningsih, P. 2018. Preliminary Phytochemical Analysis and Larvicidal Activity Of Edible Fern (Diplazium esculentum (Retz) Sw.) Extract Against Culex. Jurnal Natural. 18(3): 141-147. 